\section{Wheatstone's wheezes on show}

\section{by John Hall}

IT comes hard to be told that Sir Charles Wheatstone actually didn't invent the bridge of the same name, but such was the range of that scientist's inventiveness and imagination that one feels he must, on balance, be forgiven what amounts to a fairly minor omission. Bridges apart, he made fundamental contributions to the study of electrical measurement in the 1830 s and $1840 \mathrm{~s}$, and in the process he happened across principles of transmitting electrical impulses which formed the basis of modern telecommunications systems. As if that were not enough, he spent his twenties experimenting with musical instruments, and managed as the pièce de resistance of this period an invention which was to become the fisherman's friend. Letters patent granted by George IV in 1829 described his creation as "a certain improvement or improvements in the construction of wind instruments"; it was the concertina, successor to earlier brainchildren like the 32-key Wheatstone symphonium (pocket-sized and powered by breath), and precursor of mighty wheezers like the 81-key Wheatstone duet, with the range of a piano. The inventor's nail fiddle, a poor relative of the African thumb piano, made of nails to be scraped with a violin bow, was less of a raging success.

But Wheatstone of Wheatstone's Music Shop, Islington. clearly had a novel turn of mind, as the scientific community discovered when he was appointed Professor of Physics at King's College, London. His interest in the transmission of sound vibrations led him to experiment with the transmission of electrical impulses, and to measure their speeds along wires. His success in sending information by this means led to the needle telegraph on which the developing railway system came to depend for its signalling, the $\mathrm{ABC}$ telegraph, an automatic Morse transmitter, a punched-tape Morse transmitter and Wheatstone's printing telegraph, which in operation was akin to a Telex printer. For the record, Wheatstone's contribution to the measurement of voltage, current and resistance was that he produced an accurate calibrated variable resistance to replace the unreliable galvanometric instruments available at the time. Later prophets will also be sad to learn that the linear motor was invented by Wheatstone in 1842: given a larger current, it might have proved his brightest wheeze.

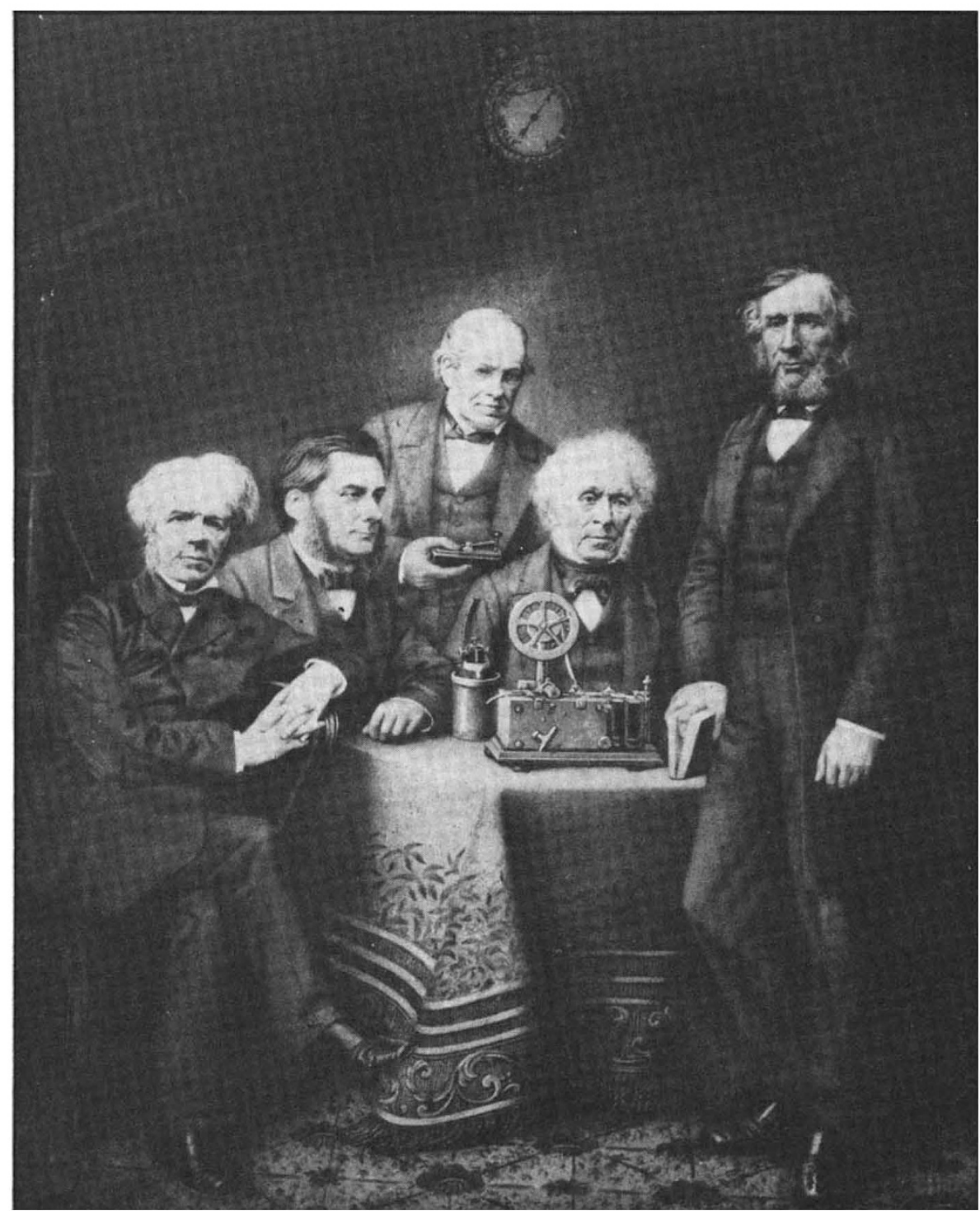

$\mathrm{He}$ was also responsible for the introduction of the Royal Institution's practice of locking lecturers in a room immediately before they are due to lecture; apparently, on one occasion when he was about to give a public discourse, Wheatstone's nerve went at the last minute, and he disappeared from the scene, leaving Faraday to ad lib the evening away.

Wheatstone is one of two eminent Victorian members of King's College to be honoured by an exhibition there this summer. The other is Sir Charles Lyell, an equally prominent and worthy man in his field of geology, but affording rather less tangible tokens of his life's work than does Wheatstone. Lyell established the main principles of geology, and amazed the learned of his day by showing that the Earth was about 4,000 million years old when you would have sworn it wasn't half that age. This scale managed to accommodate the Darwinian theory of evolution, and also gave cosmological theories a realistic time perspective, but doesn't sit conveniently in an ex- hibition display cabinet. By way of compensation there are some nice photographs of the Lyell family seat, a moderately accomplished watercolour by the man himself, and a body of evidence which testifies to the meticulous nature which the documentation of his theories must have demanded. Even as a child he collected shells and bones for his private museum, and when he wrote home to Papa it was in Latin. But he was not such a scholar that he closed his eyes to the exigencies of the world outside his books; after a page and a half of Latin, written from Midhurst Grammar School in 1814, he blurts out in the mother tongue: "If I write any more in Latin I shall miss the post."

The exhibition, at King's College, Strand, London, continues until September 10 .

The picture shows the shining lights of Victorian science (left to right): Michacl Faraday, Professor T. H. Huxley, Sir Charles Wheatstone, Sir David Brewster and Professor John Tyndall. 